36

地 學 雜 誌

この方面の研究は地質構造の研究結果て對比されて, 奇一䊬の飓價を發揮するもので，鑛床特に富鑛帶の探鑛 等應用の面からも，今後签々發展させをいものである。

\section{II. 鑛液の起源についての論爭}

從來鑛床は花崗質岩に屡々件うここから, 鑛液性花崗 質岩の根源たる岩漿溜より導かれたものさ考えられてい ๖. 然己岩石學の進步に件つて近年益々花稆質岩の中に は, 水成岩類がその場所に於て變成作用乃至交代作月(花 崗岩化作用)によつて生ごたものが多い事が明かになつ て來た・隨つてこれに绊う鑛床の起源芯何に求めるぺき かの閣題から更に進んで一般に鑛液は地款中の如何なる 深さに根源を有するかの問題について改めて檢討の必琶 を生ごて來た、以下にこれに關聯する論交在抄錄する。

1941 年 Locke は變成起源の花崗岩に伴う鑛床は前者 の原岩たる水成岩から篔かれたものか否かに就いて疑問 た提起己，二の種の花崗岩は泥質の堆積物が再結晶こた るので, 鑛液の根源は海底に堆積こた砾震物であるこ考 えた・坡はSierra Nevadaの變成起源の花崗岩飞漸移 關係にある黑色片岩中には、この地方で探堀されるあら ゆる種類の金屬の痕跡在含むここから，片岩の變成作用 の一部そこて, これら会有金屬の分化が起つたるのさこ た.

Kinstry（1941）はニれ危否定己，變成起源の花崗岩は 䂟漿源の溶液の交代作用によるものである゙さ斷ど，厉の 交代作用は早期の廣篹園に及ぶ母岩の變質で, 鑛床の生 成はこれて同ご作用によつて出來るもので，唯前者より る後期で, 隨つて低温になつた時の作用こいうに過ぎな いささた。

Loughlin (1941) は生金屬鑛床の起源は底盤の迸入後に 地下深所で起つた分化の產物で; 隨つて屡々底盤よりる 後部に迸入こた岩石を体うものであるとこた。

Anderson（1942）は Kinstry の說兔支持し，岩漿部 未期の溶液による花崗岩化は鑛化作用の最早期死代表す るものさこた・更にIdahoに於て局部的に花崗岩化され
第 $E \in 8$ 號

ろ所に鑛床が發達することに對する成因考察に當つて， 花崗岩伦を起己た溶液さ鑛液さの起源危 Loughlin 樣に隣接する迸大岩よりも深い所に求めた。

Dunn (1942) は印度の花崗岩の成因に於て溶液の浸潤 下の再結晶作用走强調しっにこような作用に對こて diabrochomorphism なる新語态偘つた), 鑛床の成因につ いては次のように考えている. 即ち前に地㲄中に沈澱己 た金屬鑛物は溶液の作用によつて運ばれて後に生成さる

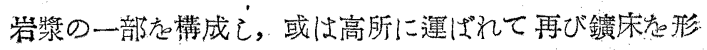
成すっものでこの移勘は著しくないため現在の鑛床區 の分布は，金屬が初めに地殻中に分布こていた狀熊先表 わするのであるどこている

White（1945）快鑛液の根源は現在一般に信ぜられて いるよりま更に深いものさ考元，鑛石岩漿は岩石岩漿の 下に別個に位置するものさこた、この兩種の岩漿の分離 は從來の岩漿說によるさ，岩漿溜內で行われるさされて

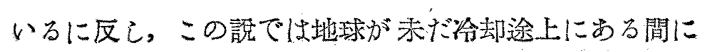
分かれたさするものである。それによると地球が呤却し て元素の結合が行われる時の鑛物生成順序は，云の生成 熱の高いものほご早々，輕い元素の化合物は一般に生成 䓡が高いために早期に生成こ，重金屬類はその後に硫兴， テルル等を結合する。

こうこて生ごた重金屬化合物は比重が大きいので重力 により地球の中心部に沈み（地款が固結を終らない前 に), 岩石岩漿下に鑛石溜を形成するさいう。

Thompson (1946)：はこれに反對已，地球は冷却中に その粘性又は剈性，內部の流動及び含有放射性物質によ る局部的な加熱等の原因によつてWhite が考えたよう な完全な分化は妨げられらここた。

要するに地球梁部についての知識の不充分な今日, 岩 石さ鑛石さの根源について適確な說圭立てるこさは不可 能では山るが、この兩者を別個のものここて考えるこさ は當圭得たまのではなく、特に後者危前者の下にこれて 無關係に㯰く必要はない区結諭した。

\title{
地形圖の讀み方とその利用 (I)
}

\author{
小 JII

\section{まえが、き}

泉*

我が國で地形圖之呼ばれている地圖は土地の賽態长正 確に現わこていっ大梯尺の地圖そいうだけでなく、全國 在統一された方針そ方法にによつて實測こ，一定の圆式 によつて衰現己たもの危指すのであつて，實際には舊陸 地測量部及び現地理調查所の發行に係方該地圖に限られ

$*$ 地理調查所
ている. 地形圖の地形（土地及びその上に載る一切の蚮 物を含无）表現の程度は梯尺の大小によつてちがうのは 當然であるが，我が國の如く地形が複雜なここるでは， 5 萬分 1 圆住相當の綜合, 省略肪施されており, 細部の 充分な表現は困壦である。こかて25,000 分1 圖では一應 之等虫解消されている之考元てよい. 現在 25,000 分 1 , 1 萬分 1 圖は局地圖そこて整備され 5 萬分 1 圖を以て 
全域圖ここているのは，地形圖の整備計亚樹立當時の或 力が然らこめた事である.

地圖はその國の文化老表徵するものであるこ云われ。 日本の地形圖は，世界各國が優秀な地圖ここて一應認め ているが如何に優秀な地圖であつてもこれ完全に讀 み充分に利用するこそができなくてはその價值はない。

\section{I. 地联圆の構 成}

一般に地圖飞呼ばれるものの中で地形圖は最も正磪な ものであり，己かもその正雄さは部分的のものでなく全 體的のものである. 何れの國の地形圖も地球の形狀の決 定に基いた，嚴密な位置さ高さを基盤さこて成り立つて かっ. 地球は眞の球體でなく棈圆體で, 我が國では心゙ッ セル氏の棈圓體尤探用こている。

$$
\begin{aligned}
& \text { 長牛徑 }=6,377,597.15 \mathrm{~m} \\
& \text { 短生徑 }=6,356,078.96 \mathrm{~m} \\
& \text { 扁平率 }=\frac{1}{2 \mathrm{c} 9.152813}
\end{aligned}
$$

站球上の正磪な位置さ高さは基準點の測量に依つて得 られる・地形圖はこの基準點在留格さこ，更に細部の测 量に依つて出來たものである。

（a）基準點測量 基準點乏は一般に三角點飞水準點 起呼えでいる。”角點は三角測量に依り，水集點は水準 測量に低つて決定される。三角測量は基線測量から出發 こて一等三角湘量，二等，三等，四等に及んで逐次地表 面上に正磪な三角點の位置即ち經緯度趋決定する事で ある. 高忡中等海水面上の高さ在以て示されている。 これは水準測量に依つて精密に測定される・(1) 基線測 量一平坦な土地 4〜8 $\mathrm{km}$ 老選えで不變鋼尺(インバー ル) 基線尺（この際原器さ比較檢定する）在以て精密に 測量古方。この誤差は 1 百葛分 $1 \mathrm{~m}$ の範圍內ここてい る. この基線寺一邊さこて附近に選ばれた地點の位置在 角觀測に基き，三角法の解法に依つて求められ：ニれ尼 一邊約 $45 \mathrm{~km}$ に擴大乞て一等點を決定する。この三角形 生正三角形に近いように選び，約 $250 \mathrm{~km}$ で基線兔設け これに閉塞していっ・この基線の兩端上の位瑥は嚴密な 天交測量に依つて決められる。我が國の一等三角测量は, 相模原基線から出發して（1883 年）萏麻布天交臺の子午 義の中心經度 $=139^{\circ} 44^{\prime} 30^{\prime \prime}$,，970 緯度 $=35^{\circ} 39^{\prime} 17^{\prime \prime}, 5148$ 危 經䋨度原點さこて同點から鹿野山一等三角點に至る方位 角によつて夓地學上の位置は決定されている。(2) 三角 測量一一一等三角測量は一邊 $45 \mathrm{~km}$ の邊辰でありその 位置は經緯度秒の小數 4 位迄計算してあり，一等の補點 は一等點の間へ邊長 $25 \mathrm{~km}$ で測量して定められる。 等は邊長 8 料在一等點, 補點を基礎さこてこれらの點の 中八測量己て決䇥する。

三等 1 邊長平均 $4 \mathrm{~km}$ の間隔に設けて秒以下 3 位迄求

めてめり，四等以下同樣に決定される（）水準測量一 一海水は潮汐の影響赽受けて常に變動している。そこで 潮の干滿を長い間測定己た值の平均潮位を中等海水面さ ここの海水面が高さの基準さなり，又投影の基準面さな るのである。我が國の中等海水面は東京灣の中等潮位で あり, これが水準原點（舊陸地測量部構內に在り）に實 在の高さで現われていっ. 水準測量はこの原點から出發 こて $2 \mathrm{~km}$ 等に標石危埋めて, 直接水準測量に依つて嚴 密に測定される.水準测量も延長 $250 \sim 300 \mathrm{~km}$ で閉塞己 これが誤差起配布して各水準點の高さが決定されるので ある. 三角點の高さは三等三角測量實施の際, これら水 準點から直接に適當な三角點の高さ在測量して、これか ら間接的に他の三角點の高さ起決定するのである.

我が國の三角點の數は 3922 點，水準點の數は 10173 點，5萬分I地形圖一圖葉中に概ね 50 點の割合で配置 こてある。

（b）投影 中等海水面が投影面であるこは前に述べ たが，地球の形狀は椿圓體であり，これを地圖即ち本面 に表現するためには適當な投影法を選ばねぱならぬ。地 形圖には多面體投影方゙探用されている，即ら一定の間隔 の經線，緯線で地球表面を切り，々の一區劃を之に切す ち本面に投影したもので、これらの本面が多く集まつて 地球を現わす事から多面體投影さ呼ぱれている。一定の 閒隔は次の通りである。

$\begin{array}{ccc}\text { 梯尺别 } & \text { 經度差 } & \text { 緯度美 } \\ 5 \text { 萬分 } 1 & 15^{\prime} & 10^{\prime} \\ 2.5 \text { 萬分 } 1 & 7^{\prime} 30^{\prime \prime} & 5^{\prime} \\ 1 \text { 萬分 } 1 & 3^{\prime} & 2^{\prime}\end{array}$

多面體投影は次の如き性質在具借さている。經線綡 線が賽長で現わされている。 ○面積も正こく表現され る. 即ち等積投影である. 05 葛分 1 以上の大梯尺圖で は經緯線は直線であり，正梯形在な己ている，○縱又は 横にのみ貼り合わせる事は可能である方縱，横さもに均

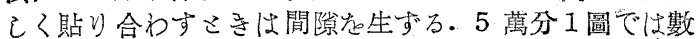
圖葉は接合可能であるがそれ以上は困蜼である。

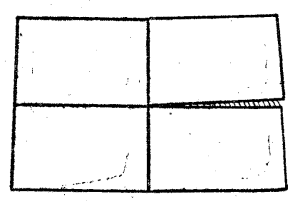

第 1 圆 多面體投影の圖 (c) 細龍測量 基準點在圖 紙 (伸縮の少い曆紙)上に嚴密 に移記し，これ基璴さ己て， 測板又は竄真測量によつて, 細 部の測量虫實施己，圖式を適用 こて現圖される。

(d) 圖式 圖式は地表面上 の諸物體走婳現する一つの規約であつて讀圖上の混亂を 避ける爲の手段であり，地圖ここての整つた統一を與え ち方法でもある。この圖式恼總括的に適用される事項飞 或る特定のものに適拥される事項こに分ける事が出來る

先ず總括的事項に就て見るに，地圖には备種の線を用 
けてて輕重要度在表現する一色刷と，各姴素危異つた色さ 濃淡で現わこた多色刷さがある.多色刷は一見こて地表 面の各娳素苍把握する有效な手段である，現在地理調查 所で發行されている地形圖は一色刷在主さこている。地 形圖に使われている線の種類は第 2 圖の通りである.

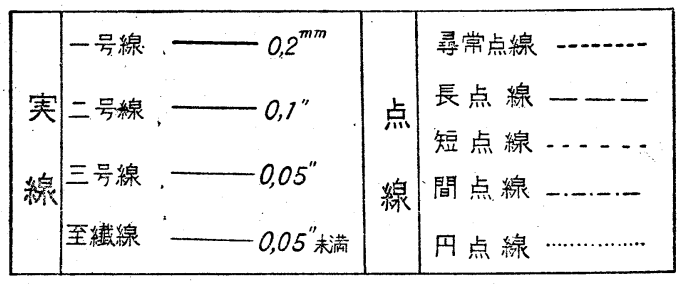

第2圖 線の種 類

地圆は北范上方にする。地形圖は圖郭線志經線（子午 線)さ,緯線(本行圈)で現わこている。故に磁石の北さは 必ず己も一致己ない。磁石は我が國では概久西偏 $5^{\circ}$. 附 近危示すものである. 公の他, 地表面及び物體の凹凸の狀 熊を現わすため一般に西北 $45^{\circ}$ の方向から光線が照らす

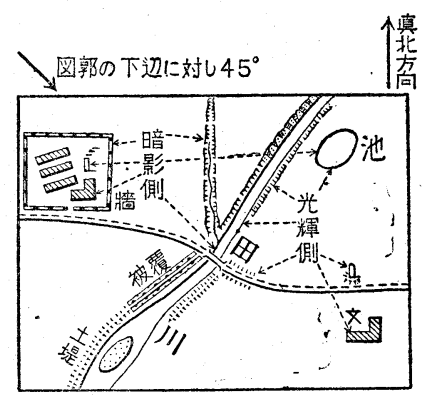

第3 圖、地圖の方位
ものさ假定こて凸 起物體には東南に 薟长附已回陷物體 には西北に陸圶附 す.更に圆式快地 物, 地貌, 註記, 整飾に分類する。

特殊事項は地物 圖式, 地貌圖式, 註 記等苋含主・地物 そは地貌壳除いた 一切の自然物及人工物在總稱する。地形圖は地物区地貌 の訔の形危圖形で表現己，圖形げけで現わ己得ない事項 走交宇で補うのが原則であるが，梯尺に依つて真形で現 わ己得ない場合がある。これはなるべく實物危連想己得 るような記號を設けて現わしてある。河川, 湖沼, 居住 地は梯尺に關係なく貟形で表わすここになつているがそ の他の物では一切記號化こている。

（1）家屋及居佳地家屋は一般に大小，集散の狀況 によつて真形, 黑描, 總㩰こて現わす。各々の梯尺に化し た大さが $0.5 \mathrm{~m}$ の方形以上のものは光輝側危三號線, 暗 影側危一號線之己前述の光線の方向に本行に至繊線で $0.3 \mathrm{~mm}$ 間隔の平行線龙入れる。この大きさに满たない ものは黑描方方。之在黑抹家屋さいう.市街地久《家屋が 連列密集己ている所は連合總描己，之老總描家屋という。 家屋が密集こていても小家屋であつて總描こた場合に狀 況危表現己得ないものは, 黑抹家屋龙密集己て現わす。 いま梯尺別に家屋描現の程度を示せば次のようである。 5 萬分 1 圖 總合及省略する。

25,000 分 1 圖 概久實況龙描示する。

1萬分1圖 交街地を除いて適磪に現況通りに婳示す る.

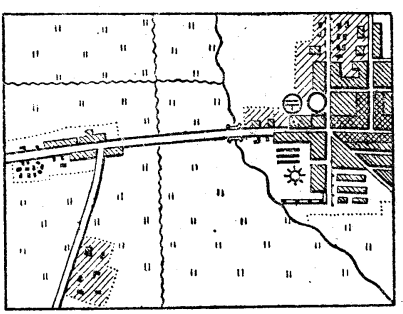

第 4 圖 家屋及居住地

市場等に見られる 無壁家屋は家旦線在 點線で現わとて山 る。

特殊家臸(一般家 屋乞區別已說明在要 するもの) が總描家 屋中にある場合は, 二號線で區劃線在入 れるか, 小點起以て 之れ在指示する，家屋密集己剷店軒を兹べ多くの物資が

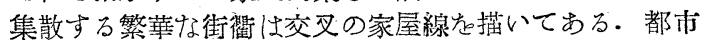
村落で家屋の周圍が樹木, 竹林等でおおわれている部分 は家屋線己反對の方向に粗に平行線が描いて山る. 都市 では綠地帶であり, 部落では特質在知る一要素でもある。

構園 (塀, 垣等) 《展望通過の障害の程度危現わ主 のさこて各梯尺を通こて，圖上長度 $3 \mathrm{~mm}$ 以上在探用己 ておるが, 目慓物體こ己て或は聚落の特長在知る一要素 こなるものである・

(2) 副記號 日常生活に密接な關係ある特殊な家屋 (神䇇, 郵便局, 役所等) 在示すために各々記號在定めて ある. これ在副記號さいう・副記號は一般に家屋の内部 か，上方に摸く起通例ここているが：この記號によつて 重要な他の地物危抹殺す万場合は, 適宜制讀己得る位置 にこれ起描く・

\begin{tabular}{|c|c|c|c|c|c|c|c|}
\hline \multirow{2}{*}{$\begin{array}{l}\text { 平 } \\
\text { 面 } \\
\text { 図 } \\
\text { 形 }\end{array}$} & $\therefore$ & + & 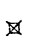 & मू & $\phi$ & 具 & $\#$ \\
\hline & 門 & 居 & 塔 & $\begin{array}{l}\text { 高 } \\
\text { 塔 }\end{array}$ & $\begin{array}{l}\text { 燈 } \\
\text { 箠 }\end{array}$ & $\begin{array}{l}\text { 石 } \\
\text { 段 }\end{array}$ & $\begin{array}{l}\text { \# } \\
\text { F }\end{array}$ \\
\hline \multirow{2}{*}{$\begin{array}{l}\text { 高 } \\
\text { 面 } \\
\text { 図 } \\
\text { 形 }\end{array}$} & 1 & a & L & $L$ & [ิ" & $Q$ & $\Lambda$ \\
\hline & 墓 & 記 & 像 & $\begin{array}{l}\text { 立 } \\
\text { 標 }\end{array}$ & $\begin{array}{l}\text { 煙 } \\
\text { 突 }\end{array}$ & $\begin{array}{l}\text { 独 } \\
\frac{\bar{u}}{\text { 䄈 }}\end{array}$ & $\begin{array}{l}\text { 起 } \\
\text { 重 } \\
\text { 機 }\end{array}$ \\
\hline
\end{tabular}

第 5 圖 小 物 體
（3）小物體 梯尺化已た場合描 き得ないような小 さい物體でも用圖 上目標さなる物體 は記號死設けてそ の所在危示す. こ れ走物體さい う.小物體は記號 が平面圖形をして いるものはその中 央が眞位置であり, 側面から見た高面圖形危てているる のは，下方中央が點位置龙現わこている。

（4）指示記號 歷史上, 地理上有名な場所は記號在 その中等位置に描き特徵のある地域㤂示す.これを指示 記號さいう・

（5）交通路 道路は記號道路己獸幅道路こに分けて あ万. 記號道路は國道, 府縣道の如く賛格によるものさ, 里道以下の如く主ここて路幅によつて現わこているもの こがある.國府縣道は交會部及圖郭線に接する所に道幅 記號を描いてその幅員在現わこてある・県幅道路は办街 地その他家屋が密集さている所で, 記號道路のために, 家屋の狀況が表現されない時に適拥己，梯尺化己た幅員 で現わす。もこ梯尺化こた值が $0.2 \mathrm{~mm}$ に滿たないもの でも， $0.2 \mathrm{~mm}$ に描く. 㬝通鐵道は軌閒 3.6 呎以上のも のであり, 特殊鐵道はそれ以下゙のものであり, 特殊鐵道 恃々れ以下のものである。但己市街電車の如きものは, 軌間の大小に拘らず，特殊鐵道己こて現わててある。

（6）境界 一般に境界は上位のもので下位のものた 悽ねろが，府縣界さ國界が一致己た場合は $2 \mathrm{~cm}$ ずつ記 
號危交互に配する。特に注意すべきは境界が河川，道路 等, 線狀物體に沿方場合は, 分岐部及圖郭線よV $1 \mathrm{~cm}$

\begin{tabular}{|c|c|c|c|c|c|c|c|c|}
\hline \multirow{3}{*}{ 耕 } & $\Pi$ & $"$ & $\Perp$ & 4 & $x$ & $\therefore$ & ${ }^{\circ}$ & $\circ$ \\
\hline & & $t$ & & $\pi$ & $\not 3$ & & 里 & 植 \\
\hline & $\begin{array}{l}\text { 畑 } \\
\text { 地 }\end{array}$ & $\begin{array}{l}\text { 乾 } \\
\text { 田 }\end{array}$ & $\begin{array}{l}\text { 水 } \\
\text { 田 }\end{array}$ & $\begin{array}{l}\text { 治 } \\
\text { 田 }\end{array}$ & $\begin{array}{l}\text { 渠 } \\
\text { 畑 }\end{array}$ & $\begin{array}{l}\text { 余 } \\
\text { 畑 }\end{array}$ & $\begin{array}{l}\text { 桔 } \\
\text { 園 }\end{array}$ & $\begin{array}{l}\text { 箖 } \\
\text { 喝 }\end{array}$ \\
\hline 未 & 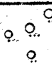 & $\begin{array}{c}A_{1} \\
A_{1}\end{array}$ & 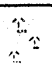 & 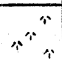 & at" & ${ }^{*}$ & $2 \pi$ & $\pm v$ \\
\hline 耕 & 濶葉 & 鍼葉 & 竹 & 篠 & 荒 & 锈 & $\begin{array}{l}\text { 棉 } \\
\text { 棁 }\end{array}$ & 燒 \\
\hline 地 & $\begin{array}{l}\text { 樹 } \\
\text { 林 }\end{array}$ & $\begin{array}{l}\text { 樹 } \\
\text { 林 }\end{array}$ & 林 & 地 & 地 & 松 & 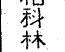 & $\begin{array}{l}\text { 不 } \\
\text { 林 }\end{array}$ \\
\hline
\end{tabular}

第 6 圖 地類記號の圖
その方向に描いて, 中間は省略してある.境界の未定の部 分は圖郭外上邊右方の行政所屬區分の所に示己てある.

（7）地類 土地表面の植物の種類を明らかにするた めに記號危以て示こてある。地類朱耕地と未耕地に分け, 耕地は定間隔に，未耕地は不規則に記號を配置こてある。

未耕地中，通過の困䧼な部分にほ地類記號々稍々同數 で小圆點が描いてある。登山，踏查等の場合，通過困難 部は特に注意在姴する。

（8）河川 梯尺化已た河幅 $0.2 \mathrm{~mm}$ 末滿の自然河川 は蛇行狀で，人工河川は解絲狀に現わこてある。. 河幅 $0.2 \mathrm{~mm}$ 以上は 2 本の線で賽際の幅に描いて山る。 1 萬 分 1 では $1 \mathrm{~m}, 2$ 萬 5 千及び 5 萬分 1 では $2 \mathrm{~m}$ 以上の

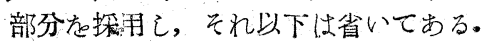

\section{社會 科 と地 理 學}

\section{青 野 壽 郎*}

終戰後わが國の敉育はおらゆる面におい一一大改革が 行われ，又現に進行しつ〉おる．六の一つここて小學校 ・新制中學校及び 新制高等學校にお河方呚科目の改正が ある、學校敉育の磪立已た明治初年以來, 敎科目は決已 て固定したものではなからたが，今国のような大改正は 初めてである。從來の敎科目になれていた學校呚師及び 一般㛇會人の多くは聊さか惑いせざる在得ないここさ

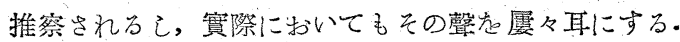
呚科目の大變革中最大のものは從來の地理・歷史・公民・ 修身な゙゙の學科が沙え，その代りに社會科が新たに誕生 とたここである。

かくて沙滅さた地理・歷史・公民・修身なごが渓會科の 內容さなつたわけであるから關係諸學怯乞れぞれの專門 的な學問の立場から活潑な批制が行わるべきである。な ぜならこの社會科が果こて新日本の敎科目さこて合理性 有有するか否か生，わ礼わ园民の重大關心事であり， 交部省の案も單なる試案に過ぎないここ妾部省自身る 認めている加らである。私は地理學徒の立場から㼛會科 について教えているこさ在若干概略的に瓝べ，社會科擔 任㸚師のみならず，世の識者の御參考に供こたいて思う・ まず最初に，地理・歷史・修身・公民の敎科目在廢こて 社會科に統合さたこさに管當性があるか否かさいう問題 である。

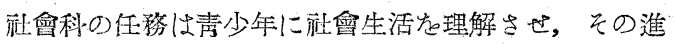

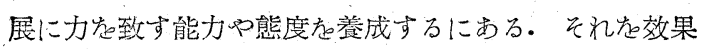
的に行う天为從來の分化していた地理・歷史・修身・公民 （內容は主に法律・經濟）なごの學問の體系を青少年に敎 え迄主方式龙やめ，直接青少年の現實生活の問題をさり 上げそれ㤂中心さこて自學自習の方式で學習せさめ，敉
師はそれ走正しく指導するのである。

從來の學校教育は青少年の經驗領域花稌り重視ぜす， 分化した多くの成人のつくり上げた學問在青少年の心理 的發澾階梯に應じて授りる方式が探られていた。々れが ため青少年の生活經驗から游離する結果危招き，长の結

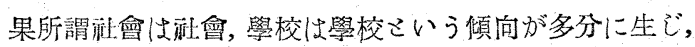
かくて養成された國民棜會生活の賽熊に直面するこ, それ志正己く理解己，合理的に處理する能力在發揮己難 い缺郋态露旺せざる起得なかつた。

青少年に分化己た學問の簡易なも息別々の敉科目己 こて授け; 彼等の生活經驗危深めてゆ人方式は年齡の若 いほご無理であるを考えられるから學間の未分化の形さ とて綜合的に取报つてゆく方が青少年の心理に合致する こいう主張は敎育の能率化さいう觀點からいつて正さい

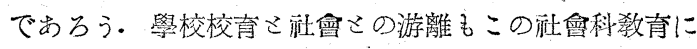
よつて解消され，青少年は自己の生活起絶えす科學的に 考える習慣危身につ沙, 社會の進展に貢嗝已得る能力在體 得できるであるう. 又從來の學校敎育は地方の特殊性色。 餘り顧虑せず, 全國劃一的に行われる傾向が强かつたが, 社會科は备地にお汀る青少年の生活經驗在重視こなりれ ぱならないから地方的に適合した教育が行われるこささ なりっこの點る從來の敎育法より合理化されるであるう。

一方，社會科に吸收された㕁科目の學閣的立場からい つても單に敎科目てしての名稱が消えたさいうここだけ では反對ずべき理由はないて思う・而もこの教育法によ る方が寧る將來分化さた社會科學の各部門死學ぶ基礎的 知識や考え方, 能力, 態度がょり一層青少年の身につく のではないかと考えられるのである．從つて私は地理學 の立場から考えてもこの社會科の呚育が交部省の姴望す るように行われたら從來の㸚科書本位の地理教育よりる 